\title{
Triploid Oysters In The Chesapeake Bay: Comparison Of Diploid And Triploid Crassostrea Virginica
}

\author{
Lionel Degremont \\ Virginia Institute of Marine Science \\ C Garcia \\ A Frank-Lawale \\ Standish K. Allen Jr. \\ Virginia Institute of Marine Science
}

Follow this and additional works at: https://scholarworks.wm.edu/vimsarticles

Part of the Marine Biology Commons

\section{Recommended Citation}

Degremont, Lionel; Garcia, C; Frank-Lawale, A; and Allen, Standish K. Jr., "Triploid Oysters In The Chesapeake Bay: Comparison Of Diploid And Triploid Crassostrea Virginica" (2012). VIMS Articles. 342. https://scholarworks.wm.edu/vimsarticles/342 


\title{
TRIPLOID OYSTERS IN THE CHESAPEAKE BAY: COMPARISON OF DIPLOID AND TRIPLOID CRASSOSTREA VIRGINICA
}

\author{
LIONEL DÉGREMONT, ${ }^{\dagger}$ CÉLINE GARCIA ${ }^{\dagger}$ ANU FRANK-LAWALE AND \\ STANDISH K. ALLEN, JR. \\ Virginia Institute of Marine Science, College of William and Mary, PO Box 1346, Gloucester Point, VA \\ 23062
}

\begin{abstract}
Diploid and triploid Eastern oysters, Crassostrea virginica, were tested at 3 sites characterized by low or moderate salinity regimes in the Virginia part of the Chesapeake Bay from November 2005 through October 2007. Both diploid and triploid cultures were replicated 3 times by producing separate spawns from different broodstock. Ploidy had a generally consistent effect on the performance of $C$. virginica at the 3 test sites. At the end of the study, in October 2007, and across all sites, triploid oysters had lower cumulative mortality than diploids $(-34 \%)$, and greater shell height $(+25 \%)$, whole weight $(+88 \%)$, and yield $(+152 \%)$, as well as a higher proportion of market-size oysters $(+114 \%)$ than diploids. Both diploids and triploids were similarly infected by Perkinsus marinus and, to a lesser extent, by Haplosporidium nelsoni. In a closer look, growth parameters (shell height growth, whole weight, yield, and percentage of marketable oysters) were always higher in triploids than in diploids regardless of the parental source, strongly supporting the superior advantage of triploids. Similar results were obtained for cumulative mortality, but to a lesser extent as a result of the large variation in mortality for both diploid and triploid cohorts among sites, as well as a significant site-by-cohort interaction. Our report is the first clear illustration of variation for the cumulative mortality exhibited among different spawns in triploids, and comes with the lesson that care must be taken in experiments in which the goal is to test the effect of ploidy on this trait. Our results support the notion that selective breeding programs to reduce mortality, coupled with triploid production to increase growth, can further optimize yield. The best-performing replicate spawn had $80 \%$ survival after $2.5 \mathrm{y}$, and reached an average shell height of $92 \mathrm{~mm}$, weighing $142 \mathrm{~g}$.
\end{abstract}

KEY WORDS: Crassostrea virginica, diploid, triploid, oyster, mortality, growth, disease, Chesapeake Bay

\section{INTRODUCTION}

Eastern oyster populations (Crassostrea virginica (Gmelin, 1791)) in the Chesapeake Bay have collapsed as a result of overfishing, loss of habitat, decrease of water quality, and diseases (Vølstad et al. 2008). For the latter, the susceptibility of $C$. virginica to 2 protozoan parasites-Perkinsus marinus (Dermo) and Haplosporidium nelsoni (MSX) - leads to episodes of mass mortality, especially in the environmental range of the Virginia portion of the Chesapeake Bay (Ford \& Haskin 1982, Andrews 1988, Mann et al. 1991). Genetic improvements, such as selection and polyploidy, have led to new optimism about rebuilding the resource through aquaculture. Development of disease-resistant strains of $C$. virginica shows promising results with the reduction of susceptibility to both diseases (Ragone Calvo et al. 2003, Aquaculture Genetics and Breeding Technology Center 2009). Triploidy also has been popular in contributing to the growth of industry in Virginia, accounting for $91 \%$ of oysters planted in 2010 (Murray \& Hudson 2011). In other oyster species, triploids grow faster than diploids as a result of their partial sterility, their greater heterozygosity, their different energy allocations for growth and gametogenesis (Allen \& Downing 1986, Hand \& Nell 1999, Hawkins et al. 2000, Garnier-Géré et al. 2002, Normand et al. 2008), or some combination thereof. Theoretically, if triploid Eastern oysters could reach market size earlier, it would limit disease mortality (Barber \& Mann 1991), resulting in increased yields even if oysters had limited disease tolerance. A similar approach was taken successfully with juvenile oyster disease, caused by the bacteria Roseovarius crassostreae (Majoy et al.

*Corresponding author. E-mail: 1degremo@ifremer.fr $\uparrow$ Current address: Laboratoire de Génétique et Pathologie, Ifremer La Tremblade, 17390 La Tremblade, France

DOI: $10.2983 / 035.031 .0103$
2007), during which faster growing oysters reached a refuge size that improved overall survival (Barber et al. 1998, Davis \& Barber 1999).

Surprisingly, few studies have documented the effect of ploidy on the performance of the Eastern oyster $C$. virginica, especially with oysters produced by crossing tetraploids with diploids. Tetraploid $\times$ diploid crosses create all-triploid (so-called genetic) progeny (Guo et al. 1996). Only 1 study has compared genetic triploid with diploid $C$. virginica, and it focused on only 1 parameter (shell height), using 1 cohort of diploids and 1 cohort of triploids (Harding 2007). Performance among cohorts of diploid oysters can vary, however, especially for survival and disease resistance, as shown for Crassostrea gigas (Evans \& Langdon 2006, Dégremont et al. 2007) and C. virginica (Ragone Calvo et al. 2003, Dégremont et al. 2006). That is, it is not the case that experimental spawns from the same broodstock population perform the same because of the nature of "sampling" different parental genes each spawn. Variance among triploid cohorts is likely as well. Testing replicate cohorts, as we report here, provides a measure of the repeatability of the performance of genetic triploid crosses stemming from different parental sources.

Improved performance in triploids could be the result of several factors, none yet documented thoroughly: additive genetic gains may be obtained in triploids resulting from selective breeding programs in the founding diploid populations; physiological gains may be obtained from increased robustness during the usually stressful spawning period in oysters (which also corresponds with disease challenges); and, last, there may be a heterotic effect from the cross between a dissimilar tetraploid male with a diploid female. Hand et al. (2004) concluded that gains obtained through selective breeding for growth could be additive for triploids in Saccostrea glomerata. More recently, triploid C. gigas produced from crossing diploid females - selected for resistance to summer 
mortality with unselected tetraploid males - had greater survival than similar triploids produced from females that were unselected (Boudry et al. 2008, Dégremont et al. 2010). It is reasonable to assume that disease resistance will pass to triploid $C$. virginica as well, because lines with dual resistance are available.

This study involves a design that should better explain the ploidy effects on performance (mortality, growth, yield, proportion of marketable oysters, and disease status) of $C$. virginica by using various diploid and tetraploid broodstocks, comparing 3 cohorts of diploid $C$. virginica with 3 cohorts of triploid C. virginica as replicates of each ploidy.

\section{MATERIALS AND METHODS}

\section{Biological Material}

Three diploid cohorts and 2 triploid cohorts were produced in the Aquaculture Genetics and Breeding Technology Center's (ABC's) hatchery at the Virginia Institute of Marine Science located in Gloucester Point. The third cohort of triploid $C$. virginica, cohort $\mathrm{G}$, was obtained from a local hatchery in northern Virginia to represent a "typical" commercial spawn of triploids. Three disease-resistant strains of diploid $C$. virginica were crossed within strain to produce three representative "cohorts" of diploids for testing against the triploids A, B and C, which were spawned respectively in April 2005, July 2005, and July 2005 (Table 1). Cohort A is the sixth generation of the Delaware Bay line called DBY ( $c f$. Ragone-Calvo et al. 2003). Cohort B is the third generation of the DMO line that originated from crossbreeding between the DBY line and a local oyster population from the Chesapeake Bay sampled in the Mobjack Bay. Last, cohort $\mathrm{C}$ is the first generation of the DBLA line that was produced from crossbreeding between the DBY line and a Louisiana line, developed and characterized by Louisiana State University (Jerome LaPeyre, Department of Veterinary Sciences) as resistant to $P$. marinus. The line was also highly susceptible to $H$. nelsoni. For triploids, 3 cohortsnamed $\mathrm{D}, \mathrm{E}$, and $\mathrm{G}$-were produced by crossing tetraploid males with diploids females in April 2005, July 2005, and July 2005, respectively (Table 1). For cohorts D and E, fifthgeneration DBY females were used whereas unselected wild females were used to produce cohort $G$ (in the commercial hatchery). Tetraploid oysters used to produce cohort $\mathrm{E}$ were the generation $G_{0}$ of the tetraploid line originally developed from triploid Louisiana wild oysters and a diploid CROSBreed (XB) male. Tetraploids used to produce cohort $D$ were from a $G_{1}$ cross of the tetraploids noted earlier. Tetraploids used to produce cohort $\mathrm{G}$ were from a tetraploid line produced independently by crossing genetic triploids produced from tetraploids $\mathrm{E}$ noted earlier with $\mathrm{XB}$, which themselves were out-crossed to the DBY line (thus it is a composite of Louisiana, $\mathrm{XB}$, and DBY germplasm). Thus, each triploid cohort was produced from different tetraploid base populations and different diploid base populations. These crosses were completed fortuitously during the 2005 spawning season with the objective of planting out various diploid and triploid cohorts for comparison. They represent the experience that commercial growers would encounter ordering seed from various hatcheries.

All cohorts were produced following standard hatchery procedures used at the ABC hatchery. Briefly, larvae were grown to eyed pediveliger stage and set using microcultch. One month later, oysters were placed in an inland nursery next to the hatchery, and ploidy was determined by flow cytometry. When juveniles were approximately $10 \mathrm{~mm}$, they were transferred into the York River until the simultaneous deployment of all diploid and triploid cohorts for grow-out evaluation in November 2005.

\section{Field Experiment}

Sites

Oysters were deployed at 3 sites in the Chesapeake Bay in November 2005 characterized by 2 salinity regimes and therefore two expected disease pressures. The low-salinity $(<15 \%)$ site was located in the Yeocomico River at Kinsale (Fig. 1), where disease pressure is low for P. marinus (Dermo) and absent for $H$. nelsoni (MSX). The other 2 sites were medium-salinity sites (15-25\%) located in the York River at Gloucester Point and in Broad Bay, Lynnhaven River, in Virginia Beach (Fig. 1), with high disease pressures for both Dermo and MSX.

\section{Experimental Design}

The culture method used was bags fixed on rebar racks. At each site, each cohort was replicated into 3 bags of 150 oysters for survival and yield assessments. A fourth bag was added for sampling for growth and disease evaluation. At each site, oysters were grown in the intertidal zone from March to November, and in deeper water for overwintering in an attempt to avoid freezinginduced mortality. In one case, this was unsuccessful.

TABLE 1.

Pedigree of the diploid (2n) and triploid (3n) cohorts tested.

\begin{tabular}{|c|c|c|c|c|c|c|}
\hline Ploidy & Cohort Name & Diploid Broodstock* & Tetraploid Broodstock* & Spawn Date & No. of Females $\dagger$ & No. of Males $\dagger$ \\
\hline $2 n$ & A & $\mathrm{G}_{5} \mathrm{DBY}$ & & April 2005 & 10 & 12 \\
\hline $2 n$ & $\mathrm{~B}$ & $\mathrm{G}_{2} \mathrm{DMO}$ & & July 0505 & 26 & 18 \\
\hline $2 n$ & $\mathrm{C}$ & $\mathrm{G}_{0} \mathrm{DBLA}$ & & July 2005 & 39 & 24 \\
\hline $3 n$ & $\mathrm{D}$ & $\mathrm{G}_{5} \mathrm{DBY}$ & $\mathrm{G}_{1}$ Louisiana and $\mathrm{XB}$ cross & April 2005 & 10 & 6 \\
\hline $3 n$ & $\mathrm{E}$ & $\mathrm{G}_{5} \mathrm{DBY}$ & $\mathrm{G}_{0}$ Louisiana and $\mathrm{XB}$ cross & July 2005 & 26 & 3 \\
\hline $3 n$ & G & $\mathrm{G}_{0}$ wild oysters & $\mathrm{G}_{0}$ Louisiana, $\mathrm{XB}$ and $\mathrm{DBY}$ cross & July 2005 & 3 & 1 \\
\hline
\end{tabular}

* G indicates generation

$\dagger$ For D, E, and G, the numbers of females are given for the diploid broodstocks, and the numbers of males are given for the tetraploid broodstocks. DBY, Andrews DBY line; XB, Haskins CROSBreed line. 


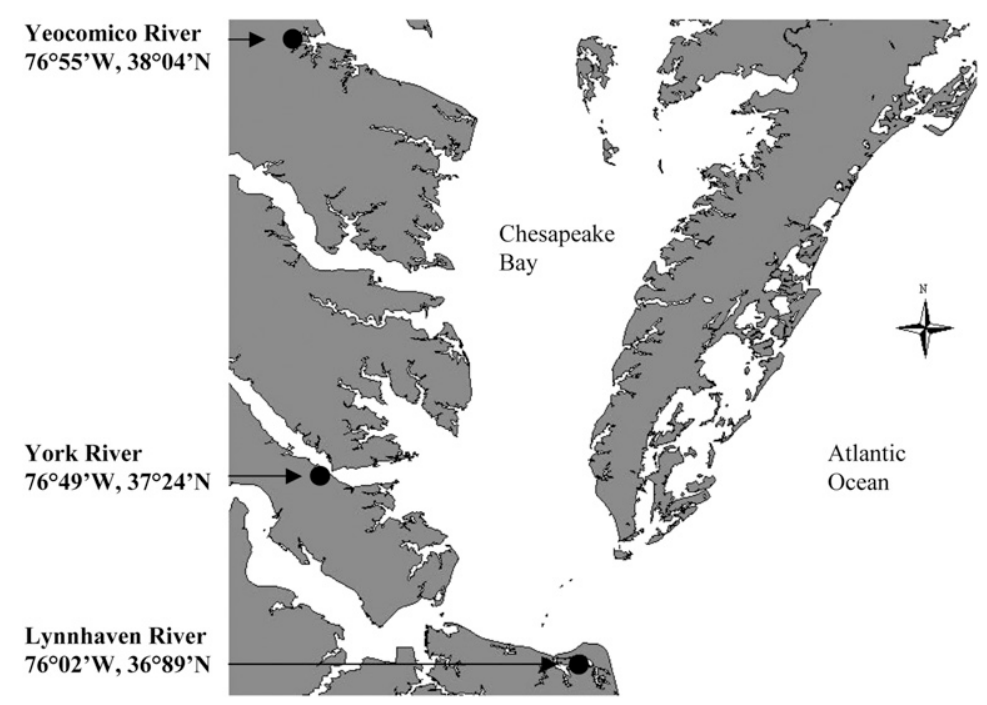

Figure 1. Location of study sites in Chesapeake Bay.

\section{Sampling and Data Collection}

At deployment, total weight of all oysters in each bag was recorded for yield assessments, and 30 oysters were sampled randomly and measured individually for shell height (in millimeters) and whole weight (in grams). Oysters were monitored from March 2006 to October 2007. Dead and live oysters were counted monthly between May 2006 and September 2006, and also in November 2006. Survival was also recorded in March 2007, June 2007, and October 2007. The cumulative mortality was then determined as the ratio between the number of dead oysters from the beginning to the sampling on the number of live oysters at the beginning. Total weight of live oysters for each of the 3 replicate bags was recorded in November 2006 and October 2007 for the determination of yield. Shell height and whole weight were measured individually from 30 oysters sampled (from the bag dedicated to growth) in November 2006 and from 50 oysters in October 2007. Percentage of oysters that reached market size (76 $\mathrm{mm}$ ) was also obtained at both dates in fall using the shell height data sets. Last, disease was assessed for all cohorts at all sites in August 2006 at the onset of heavy mortality observed for several cohorts. Fifteen oysters per cohort were screened and H. nelsoni infections were diagnosed using stained paraffin sections (Burreson et al. 1988). Parasite P. marinus was diagnosed using Ray's fluid thioglycollate medium inoculation of rectal and mantle tissues (Ray 1952). Weighted incidences were then calculated as described in Paynter and Burreson (1991).

\section{Environmental Parameters}

Temperature and salinity were recorded monthly using a YSI probe (Yellow Springs Instruments, Yellow Springs, $\mathrm{OH})$, and, in addition, temperature was recorded every $3 \mathrm{~h}$ using 2 iBCod temperature loggers (Maxim Integrated Products, Sunnyvale, CA) at each site.

\section{Statistical Analyses}

\section{Data Correction}

During the overwinter period, all racks were placed in deeper water to protect them from freezing. Unfortunately, this was unsuccessful at the Yeocomico River site. In February 2007, some of the oysters were exposed during a period of exceptionally low tide and low temperatures. Consequently, unusual mortality, ranging from 10-80\%, was observed in several bags in March 2007 ( 5 bags for the diploid cohorts and 2 bags for the triploid cohorts), whereas mortality for the remaining bags was only $1 \%$. As a result, final mortality and associated yield recorded in October 2007 were corrected for these bags. For example, two replicates of 1 cohort had low mortality $(0 \%$ and $1 \%)$ between December 2006 and March 2007, whereas the third had a mortality of $43 \%$ as a result of the freezing event. Thus, 56 oysters died of the freezing event. Of the 72 remaining oysters, 6 died from March until September 2007 ( $8 \%$ mortality). So the new number of dead oysters in September 2007 was corrected to $11(6+56 \times 8 \%)$, and the final number of alive oysters was $117(66+56 \times 92 \%)$, instead of 66 . Thus, final mortality for this replicate was corrected from $56 \%$ to $22 \%$. A total of 7 bags out of a total of 18 had to be adjusted this way. The same approach was adopted for the final yield determinations.

\section{Dependent Variables and Time Frame}

Cumulative mortality, height and weight, yield, and proportion of market-size oysters (>76 mm) were analyzed in November 2006 and October 2007. Disease prevalence for H. nelsoni and $P$. marinus, and weighted prevalence for both diseases were analyzed in August 2006, at 1+ y old.

\section{Model Equations}

We fitted the following model:

$$
\begin{aligned}
\mathrm{Y}_{i j k l}= & \mu+\operatorname{site}_{i}+\operatorname{ploidy}_{j}+\operatorname{cohort}_{k(j)}+\left(\operatorname{site}_{i} \times \text { ploidy }_{j}\right) \\
& +\left(\operatorname{site}_{j} \times \operatorname{cohort}_{k(j)}\right)+\mathrm{E}_{i j k l}
\end{aligned}
$$

where $\mathrm{Y}_{i j k l}$ is the dependant variable (mortality, disease prevalence, and weighted incidence), $\mu$ is the overall mean, site is the site effect ( $i$ is the York River, Lynnhaven River, Yeocomico River), ploidy is the ploidy effect in $C$. virginica ( $j$ is diploid, triploid), $\operatorname{cohort}_{k(j)}$ is the cohort effect ( $k$ is cohorts A, B, C, D, E, and $\mathrm{G})$, site $_{i} \times$ ploidy $_{j}$ and site $_{j} \times \operatorname{cohort}_{k(j)}$ are the interactions, 
and $\mathrm{E}_{i j k l}$ is the residual error. Site, ploidy, and their interactions were defined as fixed effects, whereas cohort and site-by-cohort interaction were random effects. We acknowledge that the "ploidy" effect is compounded by a genetic effect, such that triploids and diploids have different genetic backgrounds.

For growth (height and weight) and yield, the models were similar to those described here, except that a covariate was added: time elapsed for height and weight growth (i.e., from the deployment to the sampling) (see Taris et al. (2006) for more details). The covariate for yield was the initial yield (i.e., the total weight of the 150 oysters at the time of deployment).

\section{Statistical Procedures Used}

All statistical analyses were performed using SAS software version 9.1. Cumulative mortality, disease prevalence, and market-size oysters were analyzed using the GLIMMIX procedure with a probit transformation and a binomial distribution. The likelihood ratio test - a chi-square distribution and $d f=$ 1 -was used to test the significance of the random effects whereas the significance of fixed effects was based on F tests (Littell et al. 1996). Multiple comparisons were conducted using the leastsquares means statement and the SLICE option, which allows testing of the ploidy factor at each site when a significant interaction is found between site and ploidy. Thus, the statistical test is more powerful than rerunning the analysis within site because the degrees of freedom are not reduced (Littell et al. 2002). When a significant interaction between site and cohort was found, the site was dropped from the analyses to test the cohort effect within the site.

Normality and the homogeneity of variance for height, weight, yield, $H$. nelsoni weighted incidence, and $P$. marinus weighted incidence were assessed with the UNIVARIATE procedure using the Shapiro-Wilk statistic, and with the GLM procedure using Levene's test. From the results, the weighted incidence data were transformed using the RANK procedure, and were then analyzed using the MIXED procedure (SAS 1988). Yield was log transformed and analyzed using the MIXED procedure by running an ANCOVA with the initial yield as a covariate. A similar approach was used for the height and weight analyses except that data were not transformed and the covariate was time. Multiple comparisons were conducted using the same approach as described here.

\section{RESULTS}

\section{Salinity and Temperature}

Average salinity and SD was $10.6 \pm 2.0 \%$ at the Yeocomico River site, $16.6 \pm 2.6 \%$ at the York River site, and $19.7 \pm 1.7 \%$ o at the Lynnhaven River site throughout the experiment. Water temperature was quite similar among the 3 sites, ranging from $3^{\circ} \mathrm{C}$ during the winter to $30^{\circ} \mathrm{C}$ during the summer (Fig. 2).

\section{Cumulative Mortality}

Cumulative mortality, hereafter called mortality, by site and by ploidy recorded in November 2006 and in October 2007 is reported in Table 2. Interaction between site and ploidy was not significant in either year $(2006, P=0.617 ; 2007, P=0.897$; Table 3 ). Within and across sites, mortality was always higher in diploid than in triploid $C$. virginica throughout the duration of our study (Table 2$)$. Mean mortality $( \pm \mathrm{SD})$ across all sites was $32 \pm 21 \%$ for diploids and $18 \pm 14 \%$ for triploids in November 2006, and reached $53 \pm 23 \%$ for diploids and $35 \pm 21 \%$ for triploids in October 2007 (Table 2). Statistically, however, there was no significant difference in mortality between ploidy in both

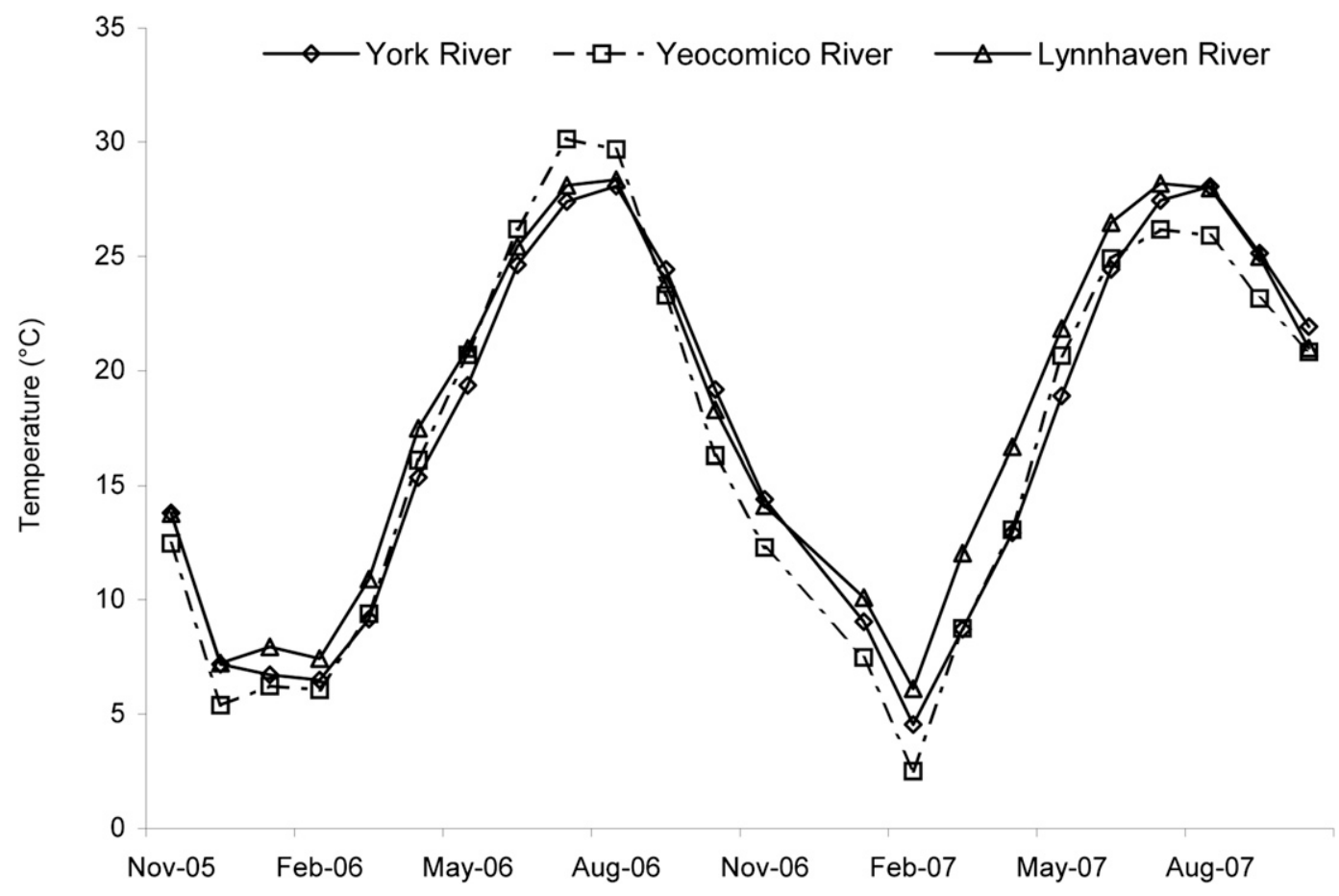

Figure 2. Water temperature at the 3 sites from November 2005 to October 2007. 
TABLE 2.

Mean and SD of diploid (2n) and triploid (3n) $C$. virginica for cumulative mortality (as a percentage) and market size (as a percentage) within and among sites in November 2006 and October 2007.

\begin{tabular}{|c|c|c|c|c|c|c|c|c|}
\hline \multirow[b]{2}{*}{ Ploidy } & \multicolumn{4}{|c|}{ Mortality in November 2006} & \multicolumn{4}{|c|}{ Mortality in October 2007} \\
\hline & Lynn R & York R & Yeoc R & All & Lynn R & York R & Yeoc R & All \\
\hline $2 n$ & $34 \pm 17$ & $48 \pm 21$ & $15 \pm 10$ & $32 \pm 21$ & $57 \pm 16$ & $70 \pm 16$ & $31 \pm 18$ & $53 \pm 23$ \\
\hline $3 n$ & $17 \pm 11$ & $26 \pm 18$ & $9 \pm 4$ & $18 \pm 14$ & $37 \pm 20$ & $50 \pm 20$ & $18 \pm 8$ & $35 \pm 21$ \\
\hline \multirow[t]{3}{*}{ Both } & $25 \pm 16$ & $37 \pm 22$ & $12 \pm 8$ & $25 \pm 19$ & $47 \pm 20$ & $60 \pm 20$ & $25 \pm 14$ & $44 \pm 23$ \\
\hline & \multicolumn{4}{|c|}{ Market size in November 2006} & \multicolumn{4}{|c|}{ Market size in October 2007} \\
\hline & Lynn R & York R & Yeoc R & All & Lynn R & York R & Yeoc R & All \\
\hline $2 n$ & $20 \pm 15$ & $3 \pm 3$ & $9 \pm 7$ & $11 \pm 11$ & $56 \pm 9$ & $21 \pm 8$ & $51 \pm 18$ & $43 \pm 20$ \\
\hline $3 n$ & $88 \pm 12$ & $62 \pm 38$ & $53 \pm 7$ & $68 \pm 25$ & $98 \pm 2$ & $84 \pm 7$ & $95 \pm 3$ & $92 \pm 8$ \\
\hline Both & $54 \pm 39$ & $33 \pm 40$ & $31 \pm 25$ & $39 \pm 35$ & $77 \pm 24$ & $53 \pm 35$ & $73 \pm 27$ & $68 \pm 29$ \\
\hline
\end{tabular}

Lynn R, Lynnhaven River; York R, York River; Yeoc R, Yeocomico River.

years $(2006, P=0.220 ; 2007, P=0.196)$, likely because of the high variance in mortality among cohorts (Table 2 ).

A significant difference in mortality was found among sites in both years $(2006, P=0.018 ; 2007, P=0.005)$, with lower mortality at the Yeocomico River site, the low-salinity site, whereas mortality was around double that at the York River and Lynnhaven River sites (the medium-salinity sites; Table 2).

Mortality remained very low for all cohorts at all sites from November 2005 to June 2006 (Fig. 3). Mortality occurred between July 2006 and November 2006, and between March 2007 and October 2007 at all 3 sites. At the Yeocomico River site, mortality remained lower than $20 \%$ for all cohorts in October 2007, except for the diploid cohort A, which reached $28 \%$ in fall 2006 and $50 \%$ in fall 2007 . At the two other sites, heavy mortality affected diploids of cohort C (57-76\%) in November 2006, whereas mortality was very low for the triploid cohort D (6-8\%) and intermediate for the other cohorts (1547\%; Fig. 3). In October 2007, similar results were observed with higher mortality that reached $77 \%$ in the Lynnhaven River and $90 \%$ in the York River for diploid cohort C, whereas mortality of the triploids in cohort D remained low (18-28\%; Fig. 3). In both years, there was a significant interaction between site and cohort (2006, $P<0.001 ; 2007, P<0.001$ ), whereas no significant differences in mortality between cohorts were found (Table 3). These results are likely a result of the variation of mortality of the diploid cohorts among salinity regimes, probably attributable to disease. Indeed, when the Yeocomico River site is dropped from the statistical analyses, the interaction between site and cohort was not significant (2006, $P=0.19 ; 2007, P=0.58)$, and there was a significant difference in mortality between cohorts $(2006, P<0.001 ; 2007$, $P<0.001)$. Also, at the Yeocomico River, mortality of cohorts was significantly different in both years $(2006, P<0.001 ; 2007$, $P<0.001)$.

\section{Disease}

Mean prevalence and weighted incidences of $H$.nelsoni across sites were $18 \pm 20 \%$ and $0.1 \pm 0.5$, respectively, in diploids, and $7 \pm 11 \%$ and $0.6 \pm 1.5$ in triploids. Within site, no H. nelsoni infection was found among cohorts tested at the low-salinity
Yeocomico River site (Fig. 4). At the medium-salinity sites, only samples from diploid cohorts $\mathrm{A}$ and $\mathrm{C}$, and triploid cohort $\mathrm{G}$ were infected at the Lynnhaven River site, whereas all cohorts except D were infected at the York River site (Fig. 4). Diploid cohort $\mathrm{C}$ had the highest prevalence and weighted incidence at the Lynnhaven River site, with $40 \%$ and 1.4, respectively, and at the York River site with $50 \%$ and 1.9 , respectively. For the mean prevalence of $H$. nelsoni, only the cohort effect was significant $(P=0.033$; Table 4). For weighted incidence of $H$. nelsoni, only the interaction between site and cohort was significant $(P=0.034$; Table 5$)$. When the low-salinity site where $H$. nelsoni was absent was dropped from the statistical analyses, however, the interaction was not significant $(P=0.53)$ and the cohort effect became significant $(P=0.037)$.

TABLE 3.

Probit analysis of mortality and market size of oysters in fall 2006 and 2007.

\begin{tabular}{|c|c|c|c|c|c|c|}
\hline \multirow[b]{2}{*}{ Source } & \multicolumn{3}{|c|}{2006} & \multicolumn{3}{|c|}{2007} \\
\hline & $d f$ & $\begin{array}{c}\text { For } \\
\text { Chi-square }\end{array}$ & $P$ & $d f$ & $\begin{array}{c}\text { For } \\
\text { Chi-square }\end{array}$ & $P$ \\
\hline \multicolumn{7}{|l|}{ Mortality (\%) } \\
\hline Site & 2 & 6.95 & 0.018 & 2 & 11.35 & 0.005 \\
\hline Ploidy & 1 & 2.11 & 0.220 & 1 & 2.41 & 0.196 \\
\hline Cohort (ploidy) & 1 & 2.31 & 0.064 & 1 & 2.20 & 0.069 \\
\hline Site $\times$ ploidy & 2 & 0.51 & 0.617 & 2 & 0.11 & 0.897 \\
\hline $\begin{array}{l}\text { Site } \times \text { cohort } \\
\quad \text { (ploidy })\end{array}$ & 1 & 229.52 & $<0.001$ & 1 & 237.78 & $<0.001$ \\
\hline \multicolumn{7}{|l|}{ Market size $(\%)$} \\
\hline Site & 2 & 5.92 & 0.026 & 2 & 12.92 & 0.003 \\
\hline Ploidy & 1 & 19.94 & 0.011 & 1 & 106.44 & $<0.001$ \\
\hline Cohort (ploidy) & 1 & 1.87 & 0.171 & 1 & 0.01 & 0.920 \\
\hline Site $\times$ ploidy & 2 & 1.17 & 0.359 & 2 & 0.17 & 0.844 \\
\hline $\begin{array}{l}\text { Site } \times \text { cohort } \\
\quad \text { (ploidy) }\end{array}$ & 1 & 6.90 & 0.009 & 1 & 6.86 & 0.009 \\
\hline
\end{tabular}

Chi-square values are in italics. Parentheses indicate nesting of factors in analyses. 

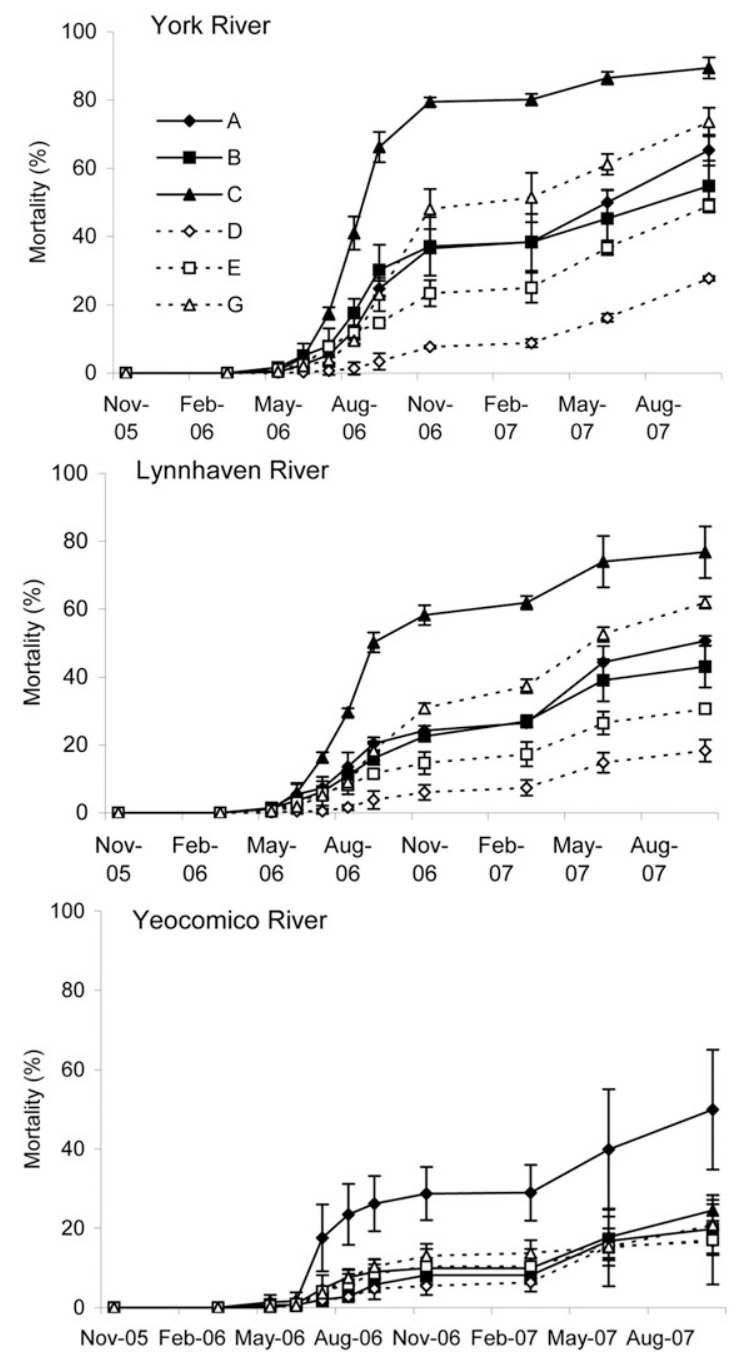

Figure 3. Mean cumulative mortality (percent \pm SD) of diploid (solid lines: cohorts A, B, and C) and triploid (dashed lines: cohorts D, E, and G) C. virginica by site from November 2005 to October 2007.

Mean prevalence for $P$. marinus within site and cohort is shown in Figure 4. The mean prevalence among sites was $33 \pm$ $29 \%$ in diploids and $39 \pm 28 \%$ in triploids, and the mean weighted incidences were $0.6 \pm 1.2$ in diploids and $0.8 \pm 1.3$ in triploids. Site effect for both prevalence and weighted incidence was significant $(P<0.001)$, as was the cohort effect for weighted incidence $(P=0.023$; Tables 4 and 5$)$. Prevalence and weighted incidence of $P$. marinus were the highest at the York River site (69 $\pm 10 \%$ and $1.2 \pm 1.4$, respectively), intermediate at the Lynnhaven River site ( $30 \pm 15 \%$ and $0.7 \pm 1.3$, respectively), and lowest at the Yeocomico River site $(9 \pm 7 \%$ and $0.2 \pm 0.6$, respectively). Cohort $\mathrm{G}$ had the highest weighted incidence $(1.1 \pm 1.5)$, and cohorts B and E exhibited the lowest weighted incidence $(0.4 \pm 0.9)$.

\section{Growth and Percentage of Market-Size Oysters}

The mean weight at deployment was $1.5 \pm 0.9 \mathrm{~g}$ for diploids and $2.4 \pm 1.1 \mathrm{~g}$ for triploids, and they grew to $41 \pm 15 \mathrm{~g}$ and $76 \pm$ $24 \mathrm{~g}$, respectively, by fall 2006, finally reaching $75 \pm 26 \mathrm{~g}$ and $141 \pm 41 \mathrm{~g}$, respectively, in fall 2007 (Table 6). In both years,

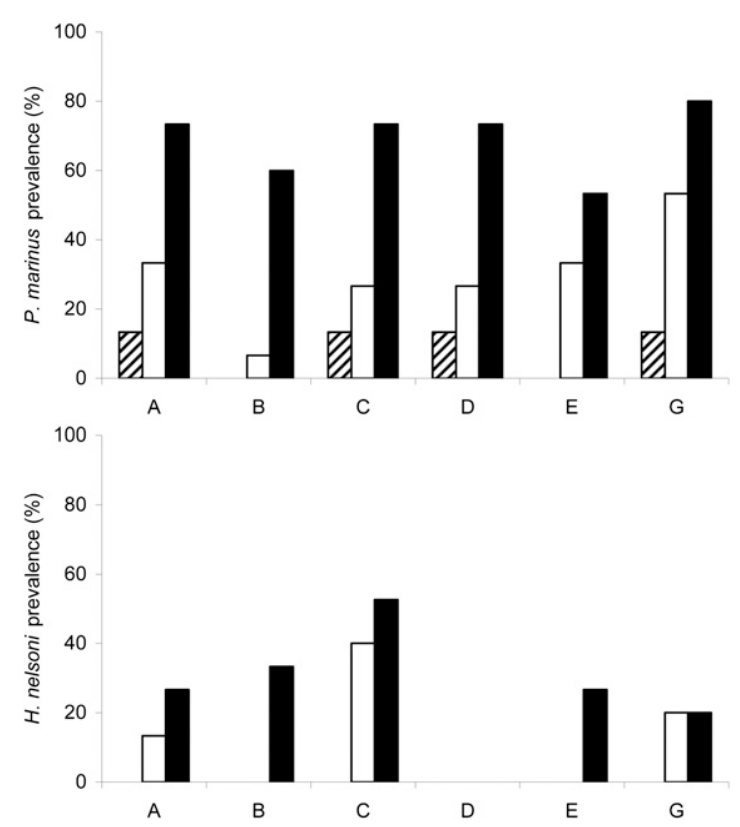

Figure 4. Prevalence of $P$. marinus (top) and H. nelsoni (bottom) in diploid (cohorts A, B, and $\mathrm{C}$ ) and triploid (cohorts D, E, and $\mathrm{G}$ ) $C$. virginica in the York River (black bars), Lynnhaven River (white bars), and Yeocomico River (dashed bars) in August 2006.

interactions between site and ploidy were significant $(P<0.05$; Table 7). Within sites, triploids always had greater weights than diploids at all sites in both years $(P<0.01$; Fig. 5). Among sites, mean weight was significantly different in both years, with the greatest weight in the Lynnhaven River, intermediate in the Yeocomico River, and the lowest in the York River $(P<0.001$; Table 7).

For shell height, diploid $C$. virginica deployed in November 2005 grew from $22-63 \mathrm{~mm}$ by fall 2006 , and from $22-75 \mathrm{~mm}$ by fall 2007. Triploid $C$. virginica grew from $28-82 \mathrm{~mm}$ by fall 2006, and from 28-94 mm by fall 2007 (Table 6). There were significant differences in shell height among sites as well as between ploidies in both years $(P<0.05$; Table 7$)$, but no significant interactions were detected between site and ploidy in either year $(P>0.05)$. Triploids grew faster than diploids; Lynnhaven River supported the highest growth rate, followed by the Yeocomico River and then the York River. There was a significant site-by-cohort interaction in both years (Table 7).

TABLE 4.

Probit analysis of disease prevalence in August 2006.

\begin{tabular}{|c|c|c|c|c|c|c|}
\hline \multirow[b]{2}{*}{ Source } & \multicolumn{3}{|c|}{ P. marinus } & \multicolumn{3}{|c|}{ H. nelsoni } \\
\hline & $d f$ & $\begin{array}{c}\text { For } \\
\text { Chi-square }\end{array}$ & $P$ & $d f$ & $\begin{array}{c}\text { For } \\
\text { Chi-square }\end{array}$ & $P$ \\
\hline Site & 2 & 34.30 & $<0.001$ & 2 & 1.99 & 0.199 \\
\hline Ploidy & 1 & 0.28 & 0.624 & 1 & 0.00 & 0.983 \\
\hline Cohort (ploidy) & 1 & 1.5 & 0.221 & 1 & 4.45 & 0.033 \\
\hline Site $\times$ ploidy & 2 & 0.83 & 0.469 & 2 & 0.03 & 0.975 \\
\hline Site $\times$ cohort (ploidy) & 1 & 0.00 & 0.980 & 1 & 0.86 & 0.354 \\
\hline
\end{tabular}

Chi-square values are in italics. 
TABLE 5.

Variance analysis of weighted incidence in August 2006.

\begin{tabular}{|c|c|c|c|c|c|c|c|c|}
\hline \multirow[b]{2}{*}{ Source } & \multicolumn{4}{|c|}{ P. marinus } & \multicolumn{4}{|c|}{ H. nelsoni } \\
\hline & $d f$ & MS & $\mathbf{F}$ & $P$ & $d f$ & MS & $\mathbf{F}$ & $P$ \\
\hline Site & 2 & 141.56 & 78.17 & $<0.001$ & 2 & 34.89 & 9.90 & 0.007 \\
\hline Ploidy & 1 & 3.78 & 0.40 & 0.560 & 1 & 21.33 & 2.19 & 0.213 \\
\hline Cohort (ploidy) & 4 & 9.38 & 5.18 & 0.023 & 4 & 9.74 & 2.80 & 0.100 \\
\hline Site $\times$ ploidy & 2 & 4.28 & 2.36 & 0.156 & 2 & 8.00 & 2.30 & 0.162 \\
\hline $\begin{array}{l}\text { Site } \times \text { cohort } \\
\quad \text { (ploidy) }\end{array}$ & 8 & 1.81 & 0.53 & 0.837 & 8 & 3.47 & 2.12 & 0.034 \\
\hline Error & 252 & 3.44 & & & 252 & 1.64 & & \\
\hline
\end{tabular}

Within site, growth was different among cohorts in all sites both years $(P<0.05)$, except in 2007 in the Lynnhaven River $(P=0.11)$.

Overall, by fall 2006 , only $11 \%$ of surviving diploid $C$. virginica reached market size $(76 \mathrm{~mm})$ compared with $68 \%$ of triploids (Table 2). It is also important to note that $90-100 \%$ of 2 cohorts of the triploid C. virginica (cohorts D and E) had reached market size - notably, at the York River and Lynnhaven River sites. By the end of the experiment, $43 \%$ of surviving diploids and $92 \%$ of the surviving triploids were market size (Table 2). Significant differences in percentage to market size were detected between ploidies in both years (Table 3 ). We also observed significant differences in the proportion of marketable oysters among sites in 2006 and 2007, with a higher proportion of oysters reaching market size in the Lynnhaven River, whereas the lowest proportion was seen in the York River (Table 6). There was always a significant difference among cohorts $(P<0.001)$ in the proportion of marketable oysters.
Last, a significant interaction between site and cohort was found for both years and within sites.

Yield

The mean yield (total weight of all live oysters) in 2006 and 2007 within and among sites and ploidies is presented in Table 6. ANCOVAs indicated that initial yield had no effect on final yield, and failed to reveal any significant site-by-ploidy interactions in either year $(P>0.05$; Table 8$)$. Triploids had a significantly higher yield than diploids in both years, with $14.9 \pm 5.1 \mathrm{~kg}$ for the former and $5.9 \pm 3.0 \mathrm{~kg}$ for the latter in 2007 (Table 6). Also, yield was significantly different among sites, with the highest yield observed for the oysters deployed in the Yeocomico River, whereas those deployed in the York River had the lowest yield in 2007 (Table 6). At the end of the experiment, yields ranged from 1.3$10.2 \mathrm{~kg}$ in the diploid cohorts, and from $5.7-22.3 \mathrm{~kg}$ in the triploid cohorts. There was a significant site-by-cohort interaction in both years, but the effect of cohort was not significant (Table 8) unless site was dropped from the statistical analyses; then, there was always a significant difference in yield among cohorts at each site $(P<0.05)$.

\section{DISCUSSION}

\section{Cumulative Mortality}

Published results of comparative oyster mortality between diploids and triploids vary. Mortality was found to be similar between the 2 ploidies in S. glomerata (Hand et al. 2004) and in C. gigas (Dégremont et al. 2010), whereas in an earlier study by Hand et al. (1998b), triploid S. glomerata (formerly Saccostrea commercialis) had lower mortality than diploid and triploid

TABLE 6.

Mean and SD of yield (in kilograms), shell height (in millimeters), and whole weight (in grams) of diploid (2n) and triploid (3n) $C$. virginica within and among sites in November 2005, November 2006, and October 2007.

\begin{tabular}{|c|c|c|c|c|c|c|c|c|c|c|c|c|}
\hline \multirow[b]{2}{*}{ Ploidy } & \multicolumn{4}{|c|}{$\begin{array}{c}\text { Initial Yield } \\
\text { in November } 2005\end{array}$} & \multicolumn{4}{|c|}{ Yield in November 2006} & \multicolumn{4}{|c|}{ Yield in October 2007} \\
\hline & Lynn R & York R & Yeoc R & All & Lynn R & York R & Yeoc R & All & Lynn R & York R & Yeoc R & All \\
\hline $2 n$ & $0.23 \pm 0.08$ & $0.25 \pm 0.12$ & $0.24 \pm 0.08$ & $0.24 \pm 0.09$ & $4.5 \pm 1.2$ & $2.9 \pm 1.2$ & $4.5 \pm 1.1$ & $4.1 \pm 1.4$ & $5.8 \pm 2.0$ & $3.3 \pm 1.6$ & $8.6 \pm 2.5$ & $5.9 \pm 3.0$ \\
\hline $3 n$ & $0.39 \pm 0.07$ & $0.41 \pm 0.07$ & $0.41 \pm 0.08$ & $0.41 \pm 0.07$ & $11.8 \pm 2.5$ & $8.6 \pm 0.5$ & $8.6 \pm 0.5$ & $9.6 \pm 2.6$ & $16.4 \pm 5.5$ & $11.0 \pm 4.8$ & $17.4 \pm 2.1$ & $14.9 \pm 5.1$ \\
\hline Both & $0.31 \pm 0.11$ & $0.33 \pm 0.13$ & $0.32 \pm 0.12$ & $0.32 \pm 0.12$ & $8.2 \pm 4.2$ & $6.8 \pm 2.0$ & $6.8 \pm 2.0$ & $6.9 \pm 3.4$ & $11.1 \pm 6.8$ & $7.1 \pm 5.2$ & $13.0 \pm 5.1$ & $10.4 \pm 6.2$ \\
\hline
\end{tabular}

\begin{tabular}{|c|c|c|c|c|c|c|c|c|c|c|c|c|}
\hline & \multicolumn{4}{|c|}{$\begin{array}{c}\text { Initial shell } \\
\text { height in November } 2005\end{array}$} & \multicolumn{4}{|c|}{$\begin{array}{c}\text { Shell height } \\
\text { in November } 2006\end{array}$} & \multicolumn{4}{|c|}{$\begin{array}{c}\text { Shell height } \\
\text { in October } 2007\end{array}$} \\
\hline & Lynn R & York R & Yeoc R & All & Lynn R & York R & Yeoc R & All & Lynn R & York R & Yeoc R & All \\
\hline $2 n$ & $21.5 \pm 5.4$ & $23.3 \pm 5.8$ & $22.3 \pm 5.2$ & $22.4 \pm 5.5$ & $67 \pm 10$ & $59 \pm 9$ & $64 \pm 8$ & $63 \pm 10$ & $79 \pm 10$ & $68 \pm 8$ & $76 \pm 11$ & $75 \pm 11$ \\
\hline $3 n$ & $27.5 \pm 5.9$ & $28.2 \pm 5.2$ & $28.4 \pm 5.5$ & $28.0 \pm 5.6$ & $89 \pm 11$ & $80 \pm 15$ & $77 \pm 11$ & $82 \pm 13$ & $102 \pm 13$ & $86 \pm 11$ & $94 \pm 11$ & $94 \pm 13$ \\
\hline \multirow[t]{3}{*}{ Both } & $24.5 \pm 6.4$ & $25.8 \pm 6.0$ & $25.4 \pm 6.2$ & $25.2 \pm 6.2$ & $78 \pm 5$ & $69 \pm 16$ & $71 \pm 12$ & $73 \pm 15$ & $90 \pm 16$ & $77 \pm 13$ & $85 \pm 14$ & $84 \pm 16$ \\
\hline & \multicolumn{4}{|c|}{$\begin{array}{c}\text { Initial whole } \\
\text { weight in November } 2005\end{array}$} & \multicolumn{4}{|c|}{$\begin{array}{c}\text { Whole weight } \\
\text { in November } 2006\end{array}$} & \multicolumn{4}{|c|}{$\begin{array}{l}\text { Whole weight } \\
\text { in October } 2007\end{array}$} \\
\hline & Lynn R & York R & Yeoc R & All & Lynn R & York R & Yeoc R & All & Lynn R & York R & Yeoc R & All \\
\hline $2 n$ & $1.4 \pm 0.9$ & $1.7 \pm 0.9$ & $1.5 \pm 0.8$ & $1.5 \pm 0.9$ & $47 \pm 16$ & $39 \pm 15$ & $39 \pm 13$ & $41 \pm 15$ & $84 \pm 29$ & $70 \pm 23$ & $71 \pm 25$ & $75 \pm 26$ \\
\hline Both & $2.3 \pm 1.1$ & $2.6 \pm 1.2$ & $2.4 \pm 1.0$ & $2.4 \pm 1.1$ & $89 \pm 20$ & $78 \pm 23$ & $62 \pm 20$ & $76 \pm 24$ & $165 \pm 46$ & $130 \pm 36$ & $126 \pm 30$ & $141 \pm 41$ \\
\hline All & $1.8 \pm 1.1$ & $2.2 \pm 1.2$ & $1.9 \pm 1.0$ & $2.0 \pm 1.1$ & $68 \pm 28$ & $58 \pm 28$ & $50 \pm 21$ & $59 \pm 26$ & $125 \pm 56$ & $100 \pm 42$ & $99 \pm 39$ & $108 \pm 48$ \\
\hline
\end{tabular}

Lynn R, Lynnhaven River; York R, York River; Yeoc R, Yeocomico River. 
TABLE 7.

Covariance analysis of growth in fall 2006 and 2007 for diploid and triploid $C$. virginica.

\begin{tabular}{|c|c|c|c|c|c|c|c|c|}
\hline \multirow[b]{2}{*}{ Source } & \multicolumn{4}{|c|}{ Growth 2006} & \multicolumn{4}{|c|}{ Growth 2007} \\
\hline & $d f$ & MS & $\mathbf{F}$ & $\boldsymbol{P}$ & $d f$ & MS & $\mathbf{F}$ & $P$ \\
\hline \multicolumn{9}{|l|}{ Whole weight } \\
\hline Site & 2 & 7.26 & 20.77 & $<0.001$ & 2 & 23.89 & 24.55 & $<0.001$ \\
\hline Ploidy & 1 & 76.85 & 59.53 & 0.002 & 1 & 354.36 & 241.72 & $<0.001$ \\
\hline Cohort (ploidy) & 4 & 1.29 & 3.69 & 0.055 & 4 & 1.47 & 1.51 & 0.288 \\
\hline Site $\times$ ploidy & 2 & 2.26 & 6.47 & 0.021 & 2 & 5.36 & 5.50 & 0.031 \\
\hline Site $\times$ cohort (ploidy) & 8 & 0.35 & 2.31 & 0.019 & 8 & 0.97 & 1.54 & 0.139 \\
\hline Error & 1,044 & 0.15 & & & 1,404 & 0.63 & & \\
\hline \multicolumn{9}{|l|}{ Shell height } \\
\hline Site & 2 & 2.48 & 7.60 & 0.014 & 2 & 5.92 & 19.56 & $<0.001$ \\
\hline Ploidy & 1 & 11.11 & 16.71 & 0.015 & 1 & 15.25 & 16.73 & 0.015 \\
\hline Cohort (ploidy) & 4 & 0.66 & 2.04 & 0.181 & 4 & 0.91 & 3.01 & 0.086 \\
\hline Site $\times$ ploidy & 2 & 0.68 & 2.10 & 0.186 & 2 & 0.20 & 0.68 & 0.535 \\
\hline Site $\times$ cohort (ploidy) & 8 & 0.33 & 5.68 & $<0.001$ & 8 & 0.30 & 3.94 & $<0.001$ \\
\hline Error & 1,044 & 0.06 & & & 1,404 & 0.08 & & \\
\hline
\end{tabular}

C. gigas (Gagnaire et al. 2006); the opposite findings were observed in C. gigas by Goulletquer et al. (1996) and Cheney et al. (2000). To our knowledge, comparison of mortality between diploid and triploid C. virginica has only been reported twice previously, and both studies used chemically induced triploids. Matthiessen and Davis (1992) found results similar to ours at one of their testing sites in New England where MSX disease was known to be prevalent, whereas mortality was negligible for both diploid and triploid oysters at sites free from disease pathogens. In a challenge experiment using oyster tissue infected with $P$. marinus, however, Meyers et al. (1991) found that there were no differences in mortality between diploid and triploid $C$. virginica because all oysters had died by the end of the trial. It is worth noting, though, that the diploids died at a faster rate and, at the time of their comparisons, disease-resistant lines were not available. In our study, overall mean cumulative mortality was $35 \%$ in triploids and $53 \%$ in diploids in October 2007 (Table 2), indicating a clear advantage for triploids in survival. The difference was not statistically significant, however, because of the high variation among both diploid and triploid cohorts, especially in the medium-salinity sites (Table 2). Such variation was observed in diploid C. virginica (Ragone Calvo et al. 2003), but not before in triploids. Our report is the first clear illustration of this variation exhibited among different spawns, and comes with the lesson that care must be taken in experiments where the goal is to test the effect of ploidy, especially under the following circumstances: (1) the diploid and triploid oysters have a low effective population size (restricted numbers of parents in the spawn), especially if the studied trait is highly heritable (that is to say, it is possible that particular individuals will lead to variation among spawns with few parents sampled within a population (Evans \& Langdon 2006, Dégremont et al. 2007)); (2) using diploid and tetraploid oysters derived from different germplasm; and (3) using the same germplasm but not the same parents, such that different sets of parents are used to produce the diploid and triploid oysters, as in the studies by Meyers et al. (1991), Matthiessen and Davis (1992), Cheney et al. (2000), Gagnaire et al. (2006), and the current study. The best method to compare diploids and triploids is to use chemically induced triploids from common females and males, or eggs from common females crossed with either the diploid or the tetraploid sperm. Even in such cases, comparisons can still break down for the latter if the diploid and tetraploid do not share common founder genotypes. In our case, this was impossible because our tetraploids were derived intentionally from a number of disease-resistant founder sources-DBY, CROSBreed, and Louisiana brood stock; there is no diploid counterpart to this tetraploid. Therefore, we replicated the ploidy factor using several cohorts produced with different spawns to partition the variation (error) in the ploidy factor and thereby increase the precision in the estimate of the difference between the 2 treatments (Hurlbert 1984).

Our study also demonstrates that triploid $C$. virginica exhibit a clear advantage over diploids even when both ploidies are disease resistant, as observed previously in S. glomerata for growth (Hand et al. 2004). Thus, it seems the progress in selection for disease-resistant strains is advanced through both the diploid and tetraploid lines (Table 1) and appears to be additive. For example, the lowest cumulative mortality in our study (Fig. 3) was observed for the triploid cohort $\mathrm{D}$, which was produced by crossing a $\mathrm{G}_{1}$ tetraploid $\times$ disease-resistant diploid line; intermediate cumulative mortality was obtained for triploid cohort $\mathrm{E}$, which was made by crossing a $\mathrm{G}_{0}$ tetraploid $\times$ disease resistant diploid line; and, last, the highest cumulative mortality was observed in triploid cohort $\mathrm{G}$, a cross between a $\mathrm{G}_{0}$ tetraploid $\times$ wild oysters. This confirms previous results in $C$. gigas that indicate that summer mortality in juveniles could be reduced significantly using a selective breeding program in both the diploid and tetraploid parents (Boudry et al. 2008, Dégremont et al. 2010). In addition to apparent disease resistance in the triploids, there may be additional effects augmenting the triploid advantage, such as nonadditive gene action, dosage effects, or simple physiological advantage. Further controlled matings are needed to sort out these possible effects on mortality.

\section{Disease}

It is important to note that disease sampling/diagnosis was only conducted in August 2006. It would have been interesting to 


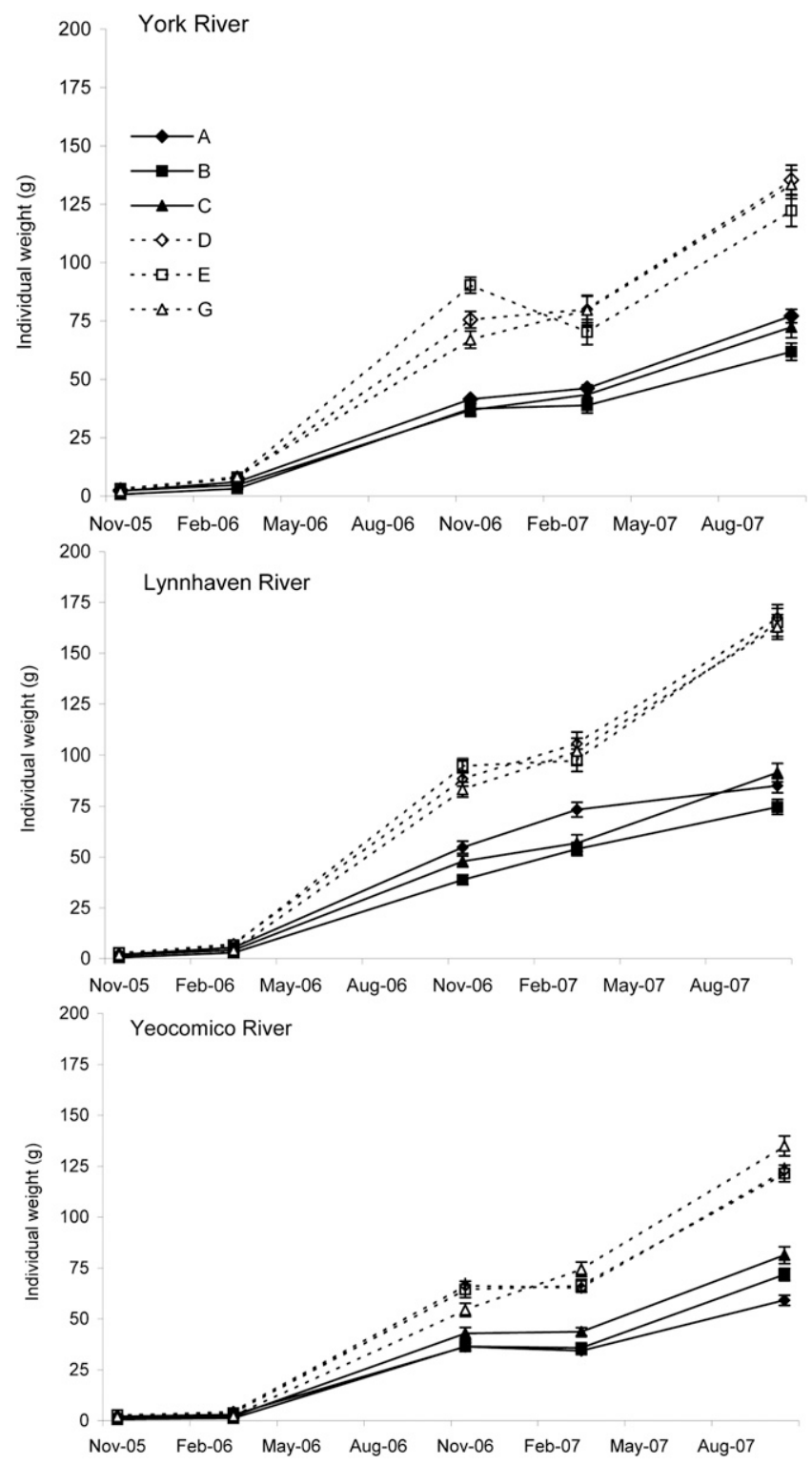

Figure 5. Growth curves of the individual weight (grams \pm SE) of diploid (solid line) and triploid (dashed line) $C$. virginica by site from November 2005 to October 2007.

gather further data in 2006 and in 2007 to determine more completely the ploidy effect on disease parameters. Nevertheless, some trends could be interpreted from the results in 2006, in relation to the mortality observed the same year. No significant difference was observed between ploidy for all disease variables (Tables 4 and 5), but there was a significant difference for the cohort effect. Perhaps this indicates that the broodstock used as parents, and so selective breeding to improve survival in C. virginica, had a greater impact than ploidy on disease. Regarding the particular pathogen involved, diploid cohort $\mathrm{C}$ suffered heavy mortality mostly as a result of $H$. nelsoni in the medium-salinity sites. This cohort was produced by crossing the DBLA line, which was a $G_{0}$ of DBY, with naive Louisiana broodstock (Table 1). Cohorts $\mathrm{A}$ and $\mathrm{B}$, produced from established disease-resistant lines (DBY and DMO), had similar survival at both disease sites. Conversely, no abnormal disease
TABLE 8.

Covariance analysis of yield in fall 2006 and 2007 for diploid and triploid $C$. virginica.

\begin{tabular}{|c|c|c|c|c|c|c|c|c|}
\hline \multirow[b]{2}{*}{ Source } & \multicolumn{4}{|c|}{ Yield 2006} & \multicolumn{4}{|c|}{ Yield 2007} \\
\hline & $d f$ & MS & $\mathbf{F}$ & $P$ & $d f$ & MS & $\mathbf{F}$ & $P$ \\
\hline Site & 2 & 0.94 & 3.13 & 0.099 & 2 & 3.01 & 5.82 & 0.028 \\
\hline Ploidy & 1 & 1.46 & 16.29 & 0.016 & 1 & 1.50 & 8.76 & 0.042 \\
\hline Cohort (ploidy) & 4 & 0.47 & 1.90 & 0.202 & 4 & 0.91 & 2.17 & 0.162 \\
\hline Site $\times$ ploidy & 2 & 0.35 & 1.14 & 0.366 & 2 & 0.29 & 0.56 & 0.590 \\
\hline $\begin{array}{l}\text { Site } \times \text { cohort } \\
\quad \text { (ploidy) }\end{array}$ & 8 & 0.30 & 50.07 & $<0.001$ & 8 & 0.52 & 23.41 & $<0.001$ \\
\hline Initial yield & 1 & 0.00 & 0.09 & 0.760 & 1 & 0.05 & 1.53 & 0.224 \\
\hline Error & 35 & 0.01 & & & 35 & 0.02 & & \\
\hline
\end{tabular}

mortality was observed for any cohort in the Yeocomico River, where H. nelsoni was not detected in 2006 (in fact, none has been detected between 2004 and 2007, data not shown). Regarding other cohorts, a significant portion of the mortality may be attributable mostly to $P$. marinus and, to a lesser extent, to $H$. nelsoni, because $P$. marinus prevalence and weighted incidence were greater than those of $H$. nelsoni.

\section{Growth and Percentage of Market-Size Oysters}

Our results indicate that weight was twice as high in triploid C. virginica as in diploids, and - to a lesser extent - a similar trend was found for shell height, clearly showing another real advantage of triploidy. Triploid cohort $\mathrm{D}$, which was the best cohort for survival, reached an average shell height of $92 \mathrm{~mm}$ and weighed $142 \mathrm{~g}$ in fall 2007. Growth advantages in oysters resulting from triploidy are common around the world (Nell 2002), and our results are similar to those observed by Hand et al. (1998a) in S. commercialis, Hand et al. (2004) in S. glomerata, and Goulletquer et al. (1996) and Garnier-Géré et al. (2002) in $C$. gigas. Previous studies in $C$. virginica have compared mostly growth between diploids and chemically induced triploids. Different responses have been reported, however, with either triploids having greater growth than diploids (Stanley et al. 1984, Barber \& Mann 1991, Matthiessen \& Davis 1992) or diploids and triploids having similar growth, depending on whether triploids were created through meiosis I or meiosis II inhibition (Stanley et al. 1984). To our knowledge, only 1 study has compared genetic triploid $C$. virginica, produced by mating diploids and tetraploids, with diploid $C$. virginica. This study reported that triploid and diploid Eastern oysters attained the same size at $1.2 \mathrm{y}$ and $1.5 \mathrm{y}$, respectively (Harding 2007), which supports our results. The results of Harding (2007) could be explained by the lack of measurements on smaller oysters combined with large differences in initial size between ploidies, taking into account that the most rapid growth is observed during the first $2 \mathrm{y}$ of life (Kraeuter et al. 2007). Interestingly, cohorts used in her study were the same as those used in ours (derived from the same spawns), with the diploid DBY Eastern oyster referred to here as cohort A and the triploid Eastern oyster referred to here as cohort D. Triploids of cohort D in our study had much greater growth than diploids of cohort A at all sites (Fig. 5), and this was also confirmed by pooling the 3 cohorts within ploidy. Thus, our study is the first to report a greater growth rate for shell height in genetic triploid $C$. virginica than diploid $C$. virginica, which was 
also confirmed through the whole-weight analyses at all sites and in both years.

Because of the superior performance in triploid oysters, most had reached market size ( $76 \mathrm{~mm}$ in Virginia) by the end of the experiment, whereas only half as many diploids had reached such a size. This agrees with results obtained from $C$. virginica tested in the York River (Barber \& Mann 1991), and C. virginica at the Fisher Island Sound site investigated by Matthiessen and Davis (1992). Our results confirmed that triploid C. virginica take less time than diploids to attain market size, which was recently estimated to be $1.2 \mathrm{y}$ in triploids and $1.5 \mathrm{y}$ in diploids (Harding 2007). Interestingly, $97 \%$ of the remaining oysters of cohort E exceeded market size in the Yeocomico and Lynnhaven rivers in November 2006, when they were 15 mo old, and $80 \%$ of them had survived. One year later, survival was $20 \%$ less $(60 \%)$. This loss during the second year would have been eliminated if the oysters had been harvested in winter 2006 instead of spring 2007.

\section{Yield}

Fast growth combined with low cumulative mortality leads to high yield. On average, among sites, the best triploid cohort (D) yielded $11.4 \mathrm{~kg}$ in November 2006 and $18.4 \mathrm{~kg}$ in October 2007, whereas the best yield for diploids was $4.4 \mathrm{~kg}$ and $7.1 \mathrm{~kg}$, respectively, for cohort B. Furthermore, the lowest yield in triploids was $61 \%$ greater than the highest yield in diploids, indicating the superior commercial traits of triploid $C$. virginica. The high variation among cohorts within ploidy, however, and the strong interaction between cohorts and environment, also indicate that specific cohorts might be tailored to specific environments, although the range of salinities in our region of the Chesapeake Bay is greater than the typical range of salinities used for cultivation in other areas along the east coast of the United States.

\section{CONCLUSIONS}

Our study clearly demonstrates that triploid C. virginica were superior to diploids in growth (height, weight, percentage of market-size oysters) and yield, and to a lesser extent in survival, indicating a significant genetic improvement of the species.
Apparently triploidy, however, does not confer an advantage in terms of disease incidence. Nonetheless, survival was greater in the triploid groups. This finding could potentially uncover the mechanism for disease tolerance in this species. Superior survival in the presence of Dermo and MSX may be the result of the physiological advantages of triploidy derived from sterility, not disease resistance. On the other hand, there is an indicationbased on the rank performance among triploids resulting from their genetic foundation from disease-resistant lines (or not)that some advantages of breeding can also be obtained. Strong variation among cohorts and strong interactions between cohorts and environments, especially between low- and mediumsalinity sites, suggest that specific cohorts should be used for each salinity regime. This tailoring of strains to environments has been a hallmark of the $\mathrm{ABC}$ breeding program, and it appears that it is warranted for triploids. Particularly intriguing was triploid cohort $\mathrm{D}$, which had a consistently high performance at all sites throughout the duration of the experiment, with the largest yield $(18.4 \mathrm{~kg})$ and the greatest survival $(80 \%)$ after $2.5 \mathrm{y}$, and reached an average shell height of $92 \mathrm{~mm}$ and weighed $142 \mathrm{~g}$. Whether generalist crosses can be produced routinely for greater yields across environments awaits further comparisons using various tetraploid "lines." In general, though, triploid C. virginica should be considered to confer a significant added value for aquaculture in this area.

\section{ACKNOWLEDGMENTS}

We thank Shane Bonnot, Ryan Gill, Nate Geyerhan, Linda Crewe, and Adeline Fortin for their help in hatchery and field operations. We also thank Karen Hudson, who conducted the ploidy analyses, and the VIMS Department of Environmental and Aquatic Animal Health - in particular, Ryan Carnegie, Eugene Burreson, Rita Crockett, and Susan Denny for conducting disease diagnoses. Last, we greatly acknowledge members of the oyster industry, including Clifford Love and the Bevans Oyster Company, for providing study sites. This work was partly funded by Grant no. NA07NMF4570311 from NOAA Chesapeake Bay Office. Contribution no. 3224 of the Virginia Institute of Marine Science, The College of William and Mary.

\section{LITERATURE CITED}

Allen, S. K. \& S. L. Downing. 1986. Performance of triploid Pacific oysters, Crassostrea gigas (Thunberg): I. Survival, growth, glycogen content, and sexual maturation in yearlings. J. Exp. Mar. Biol. Ecol. 102:197-208.

Andrews, J. D. 1988. Epizootiology of the disease caused by the oyster pathogen Perkinsus marinus and its effects on the oyster industry. Am. Fish. Soc. Symp. 18:47-63.

Aquaculture Genetics and Breeding Technology Center. 2009. The Aquaculture Genetics and Breeding Technology's oyster breeding program. Gloucester Point, VA: ABC VIMS Publications. 25 pp.

Barber, B. J., C. V. Davis \& M. A. Crosby. 1998. Cultured oysters, Crassostrea virginica, genetically selected for fast growth in the Damariscotta River, Maine, are resistant to mortality caused by juvenile oyster disease (JOD). J. Shellfish Res. 17:1171-1175.

Barber, B. J. \& R. Mann. 1991. Sterile triploid Crassostrea virginica (Gmelin, 1791) grow faster than diploids but are equally susceptible to Perkinsus marinus. J. Shellfish Res. 10:445-450.

Boudry, P., L. Dégremont \& P. Haffray. 2008. The genetic basis of summer mortality in Pacific oyster spat and potential for improving survival by selective breeding in France. In: J. F. Samain \& H. McCombie, editors. Summer mortality of Pacific oyster Crassostrea gigas: the Morest Project. Versailles: Quae Editions. pp. 153-196.

Burreson, E., M. Robinson \& A. Villalba. 1988. A comparison of paraffin histology and hemolymph analysis for the diagnosis of Haplosporidium nelsoni (MSX) in Crassostrea virginica (Gmelin). J. Shellfish Res. 7:19-23.

Cheney, D. P., B. F. MacDonald \& R. A. Elston. 2000. Summer mortality of Pacific oysters, Crassostrea gigas (Thunberg): initial findings on multiple environmental stressors in Puget Sound, Washington, 1998. J. Shellfish Res. 19:353-359.

Davis, C. V. \& B. J. Barber. 1999. Growth and survival of selected lines of Eastern oysters, Crassostrea virginica (Gmelin 179) affected by juvenile oyster disease. Aquaculture 178:253-271.

Dégremont, L., S. K. Allen, E. Burreson \& G. DeBrosse. 2006. Survival and growth of Crassostrea virginica lines in Chesapeake and Delaware Bays. J. Shellfish Res. 25:722.

Dégremont, L., B. Ernande, E. Bédier \& P. Boudry. 2007. Summer mortality of hatchery-produced Pacific oyster spat (Crassostrea 
gigas): I. Estimation of genetic parameters for survival and growth. Aquaculture 262:41-53.

Dégremont, L., P. Soletchnik \& P. Boudry. 2010. Summer mortality of selected juvenile Pacific oyster Crassostrea gigas under laboratory conditions and in comparison with field performance. J. Shellfish Res. 29:1-10.

Evans, S. \& C. Langdon. 2006. Effects of genotype $\times$ environment interactions on the selection of broadly adapted Pacific oysters (Crassostrea gigas). Aquaculture 261:522-534.

Ford, S. E. \& H. H. Haskin. 1982. History and epizootiology of Haplosporidium nelsoni (MSX), an oyster pathogen in Delaware Bay, 1957-1980. J. Invertebr. Pathol. 40:118-141.

Gagnaire, B., P. Soletchnik, P. Madec, P. Geairon, O. Le Moine \& T. Renault. 2006. Diploid and triploid Pacific oysters, Crassostrea gigas (Thunberg), reared at two heights above sediment in MarennesOleron Basin, France: difference in mortality, sexual maturation and hemocyte parameters. Aquaculture 254:606-616.

Garnier-Géré, P. H., Y. Naciri-Graven, S. Bougrier, A. Magoulas, M. Héral, G. Kotoulas, A. Hawkins \& A. Gérard. 2002. Influences of triploidy, parentage and genetic diversity on growth of the Pacific oyster Crassostrea gigas reared in contrasting natural environments. Mol. Ecol. 11:1499-1514.

Goulletquer, P., J. P. Joly, A. Gérard, E. Le Gagneur, J. Moriceau, J. M. Peignon, S. Heurtebise \& P. Phelipot. 1996. Performance of triploid Pacific oysters Crassostrea gigas (Thunberg) reared in high carrying capacity ecosystem: survival, growth and proximate biochemical composition. Haliotis 25:1-12.

Guo, X., G. DeBrosse \& S. K. Allen. 1996. All-triploid pacific oysters (Crassostrea gigas Thunberg) produced by mating tetraploids and diploids. Aquaculture 142:149-161.

Hand, R. E. \& J. A. Nell. 1999. Studies on triploid oysters in Australia: XII. Gonad discolouration and meat condition of diploid and triploid Sydney rock oysters (Saccostrea commercialis) in five estuaries in New South Wales, Australia. Aquaculture 171:181-194.

Hand, R. E., J. A. Nell \& G. B. Maguire. 1998a. Studies on triploid oysters in Australia: X. Growth and mortality of diploid and triploid Sydney rock oysters Saccostrea commercialis (Iredale and Roughley). J. Shellfish Res. 17:1115-1127.

Hand, R. E., J. A. Nell, I. R. Smith \& G. B. Maguire. 1998b. Studies on triploid oysters in Australia: XI. Survival of diploid and triploid Sydney rock oysters (Saccostrea commercialis (Iredale and Roughley) through outbreaks of winter mortality caused by Mikrocytos roughley infestation. J. Shellfish Res. 17:1129-1135.

Hand, R. E., J. A. Nell \& P. A. Thompson. 2004. Studies on triploid oysters in Australia: XIII. Performance of diploid and triploid Sydney rock oyster, Saccostrea glomerata (Gould, 1850), progeny from a third generation breeding line. Aquaculture 233:93-107.

Harding, J. 2007. Comparison of growth rates between diploid DEBY Eastern oysters (Crassostrea virginica, Gmelin 1791), triploid Eastern oysters, and triploid Suminoe oysters (C. ariakensis, Fugita 1913). J. Shellfish Res. 26:961-972.

Hawkins, A. J. S., A. Magoulas, M. Héral, S. Bougrier, Y. NaciriGraven, A. J. Day \& G. Kotoulas. 2000. Separate effects of triploidy, parentage and genomic diversity upon feeding behaviour, metabolic efficiency and net energy balance in the Pacific oyster Crassostrea gigas. Genet. Res. 76:273-284.
Hurlbert, S. H. 1984. Pseudoreplication and the design of ecological field experiments. Ecol. Monogr. 54:184-211.

Kraeuter, J. N., S. Ford \& M. Cummings. 2007. Oyster growth analysis: a comparison of methods. J. Shellfish Res. 26:479-491.

Littell, R. C., G. A. Milliken, W. W. Stroup \& R. D. Wolfinger. 1996. SAS system for mixed models. Cary, NC: SAS Institute. 633 pp.

Littell, R. C., W. W. Stroup \& R. J. Freund. 2002. SAS for linear models, $4^{\text {th }}$ edition. Cary, NC: SAS Institute. $466 \mathrm{pp}$.

Majoy, A. P., S. E. Ford, R. C. Karney \& K. J. Boettcher. 2007. Roseovarius crassostreae, the etiological agent of juvenile oyster disease (now to be known as roseovarius oyster disease) in Crassostrea virginica. Aquaculture 269:71-83.

Mann, R., E. M. Burreson \& P. K. Baker. 1991. The decline of the Virginia oyster fishery in Chesapeake Bay: considerations for introduction of a non-endemic species, Crassostrea gigas (Thunberg, 1793). J. Shellfish Res. 10:379-388.

Matthiessen, G. C. \& J. P. Davis. 1992. Observations on growth rate and resistance to MSX (Haplosporidium nelsoni) among diploid and triploid Eastern oysters (Crassostrea virginica (Gmelin, 1797)) in New England. J. Shellfish Res. 11:449-454.

Meyers, J. A., E. M. Burreson, B. J. Barber \& R. Mann. 1991. Susceptibility of diploid and triploid Pacific oysters, Crassostrea gigas (Thunberg, 1793) and Eastern oysters, Crassostrea virginica (Gmelin, 1791) to Perkinsus marinus. J. Shellfish Res. 10:433-437.

Murray, T. J. \& K. Hudson. 2011. Virginica shellfish aquaculture: situation and outlook report. VSG-11-06. VIMS marine resource report no. 2011-11. Sea Grant Marine Advisory Service, Gloucester Point, VA. $15 \mathrm{pp}$

Nell, J. A. 2002. Farming triploid oysters. Aquaculture 210:69-88.

Normand, J., M. Le Pennec \& P. Boudry. 2008. Comparative histological study of gametogenesis in diploid and triploid Pacific oysters (Crassostrea gigas) reared in an estuarine farming site in France during the 2003 heatwave. Aquaculture 282:124-129.

Paynter, K. T. \& E. M. Burreson. 1991. Effects of Perkinsus marinus infection in the Eastern oyster, Crassostrea virginica: II. Disease development and impact on growth rate at different salinities. $J$. Shellfish Res. 10:425-431.

Ragone Calvo, L. M., G. W. Calvo \& E. M. Burreson. 2003. Dual disease resistance in a selectively bred Eastern oyster, Crassostrea virginica, strain tested in Chesapeake Bay. Aquaculture 220:69-87.

Ray, S. M. 1952. A culture technique for diagnosis of infections with Dermocystidium marinum Mackin, Owen and Collier in oysters. Science 116:360-361.

SAS. 1988. SAS procedure guide, release 6.03. Cary, NC: SAS Institute. $441 \mathrm{pp}$.

Stanley, J. G., H. Hidu \& S. K. Allen. 1984. Growth of American oysters increased by polyploidy induced by blocking meiosis I but not meiosis II. Aquaculture 37:147-155.

Taris, N., B. Ernande, H. McCombie \& P. Boudry. 2006. Phenotypic and genetic consequences of size selection at the larval stage in the Pacific oyster (Crassostrea gigas). J. Exp. Mar. Biol. Ecol. 333:147-158.

Vølstad, J. H., J. Dew \& M. Tarnowski. 2008. Estimation of annual mortality rates for Eastern oysters (Crassostrea virginica) in Chesapeake Bay base on box counts and application of those rates to project population growth of $C$. virginica and C. ariakensis. J. Shellfish Res. 27:525-533. 